\title{
SCHISTOSOMA MANSONI: IMPORTANCE OF SKIN AND PULMONARY PHASES TO CONCOMITANT IMMUNITY IN ALBINO MICE (*)
}

Míriam O. ROCHA (1), Paulo Marcos Z. COELHo (2) and Rômulo T. MELLo (1)

\section{S U M M A R Y}

Fourteen-day-old schistosomula obtained from mice previously infected were surgically transferred to the portal vein of receptor mice. Another group of mice was infected with cercariae by transcutaneous route. After 90 days, those groups were challenged with 100 cercariae, transcutaneously, as well as a control group. Two 'weeks later the animals were perfused and mature and immature worms counted separately. Statistically significant differences 'were observed in the recovery of immature worms, when the control group was compared with those twice infected. No statistical difference was detected between the group infected transcutaneously, and that infected by worm inoculation in portal vein. Results demonstrated that suppression of skin and lung migration of the parasite does not interfere with the development of the so called concomitant immunity.

\section{N T ROD U G T I O N}

Protective immunity in schistosomiasis occurs in laboratory animals, and a similar im munity might develop in man.

An outstanding problem is the determination of the actual site (skin, lung or portal system) giving the strongest stimulus to the development of concomitan' immunity.

SMITHERS \& GAMMAGE ${ }^{7}$ gave evidence of two distinct mechanisms in protective immunity. One of them takes place in the skin, where the infective cercariae die, and the other, in the portal system, where the challenge parasites die. It is important to know the role of migration through the skin and lungs in the development of immunoprotection. Our preliminary results (ROCHA et al. ${ }^{5}$ ) are similar to those of PERESAN \& CIOLI 4 , who used $\mathrm{C}_{3} \mathrm{H}$ mice and S. mansoni (Puerto Rican strain). They found that mice inoculated with worms directly into the portal vein had the same de- gree of protection against challenge with cercariae as animals previously infected transcutaneously with cercariae. The same Authors considered the possibility of different mouse strains, under the same conditions, to exhibit different degrees of acquired resistance to $\mathbf{S}$. mansoni. On the other hand, DEAN et al. ${ }^{2}$ showed a close relationship between liver pathology and resistance to reinfection. So, it is possible the occurrence of different levels of pathology and resistance reiated with different strains of S. mansoni.

In the present work we studied the degree of immunity developed by Swiss albino mice in which the skin and pulmonary phases of infection were eliminated by inoculating schistosomula directly into the portal vein.

\section{MATERIALS AND METHODS}

Thirty 14-day-old schistosomula (LE strain, Belo Horizonte) obtained from mice previously

(1) Departamento de Análises Clínicas e Toxicológicas, Faculdade de Farmácia da UFMG

(2) Grupo Interdepartamental de Estudos sobre Esquistossomose (GIDE), ICB/UFMG

(*) This study was supported by FINEP and CNPq (PIDE)

Address for reprints: GIDE - ICB/UFMG, Caixa Postal 2486, 30000 Belo Horizonte, Brasil 
ROCHA, M. O.; COELHO, P. M. Z. \& MELLO, R. T. - Schistosoma mansoni: importance of skin and pulmonary phases to concomitant immunity in albino mice. Rev. Inst. Med. trop. São Paulo 27:86-88, 1985.

infected were surgically injected in the portal vein of male outbred Swiss mice, according to the technique described by ROCHA et al. ${ }^{6}$. At the same date, a group of mice were infected with 35 cercariae, by transcutaneous route, according to BARBOSA et al. ${ }^{1}$.

Ninety days later, both groups were challenge infected with 100 cercariae, transcutaneously (BARBOSA et al. 1), and at the same time a group of normal mice, of the same origin and age, were similarly infected.

Two weeks later, the animals were sacrificed and perfused for worm recovery (PELLEGRINO \& SIQUEIRA ${ }^{3}$ ). By counting the numbers of mature and immature worms, parasites of the first and challenge infections were readily distinguished. Experiments were repeated twice.

\section{RESULTS}

Results given in Table I showed statistically significant differences in the recovery of immature worms (Student's t test, $\mathbf{P}<0.01$ ) when the control group was compared with those twice infected. However, no statistically significant differences were detected between groups with double infection.

Results in Table II confirm, using a greater number of animals, that no differences could be observed between the group infected by portal vein and the group transcutaneously infected. This last experiment was repeated using only groups twice infected.

$$
\text { T A B L E } \mathbf{I}
$$

Schistosoma mansoni: recovery of mature worms (1st infection - portal vein or transcutaneous route) and immature worms (challenge infection - transcutaneous: route)

\begin{tabular}{|c|c|c|c|}
\hline \multirow{2}{*}{ Groups of mice } & \multirow{2}{*}{$\begin{array}{l}\text { Mice } \\
\text { (n) }\end{array}$} & \multicolumn{2}{|c|}{ Worm recovery (mean \pm S.D.) } \\
\hline & & $\begin{array}{l}\text { Mature } \\
\text { First infection }\end{array}$ & $\begin{array}{c}\text { Immature } \\
\text { Challenge infection }\end{array}$ \\
\hline $\begin{array}{l}\text { Previously infect } \\
\text { by portal vein } \\
\text { Previously infect }\end{array}$ & 06 & $7.33 \pm 7.23$ & $3.00 \pm 3.22$ \\
\hline transcutaneously & 07 & $11.43 \pm 6.48$ & $0.00 \pm 0.00$ \\
\hline Control & 08 & - & $24.88 \pm 10.00$ \\
\hline
\end{tabular}

\section{DISGUSSION}

Data obtained in the present work demonstrated that a group of mice infected in portal

\section{T A B L E II}

Schistosoma mansoni: recovery of mature worms (1st infection - portal vein or transcutaneous route) and imma. ture worms (challenge infection - transcutaneous route)

\begin{tabular}{|c|c|c|c|}
\hline \multirow{2}{*}{ First infection } & \multirow{2}{*}{$\begin{array}{l}\text { Mice } \\
\text { (n) }\end{array}$} & Worm recovery & $($ mean \pm S.D. $)$ \\
\hline & & $\begin{array}{c}\text { Matiure } \\
\text { First infection }\end{array}$ & $\begin{array}{c}\text { Immature } \\
\text { Challenge infection }\end{array}$ \\
\hline Portal vein & 14 & $14.07 \pm 7.07$ & $1.00 \pm 1.66$ \\
\hline Transcutaneous & 13 & $12.00 \pm 4.92$ & $1.15 \pm 1.28$ \\
\hline
\end{tabular}

vein 'with 14-day-old schistosomula develops a resistance to a challenge infection similar to that presented by a group of mice transcutaneously infected. When these two groups; were compared with the control group (not previously infected) a well marked difference could be observed in the number of worms recovered from the challenge infection. These results confirm our preliminary data (ROCHA et al. ${ }^{5}$ ) and those reported by PERESAN \& CIOLI 4 when an analogous resistance was demonstrated.

In spite of the possibility that different mouse strains may show peculiar responses of acquired resistance to $\mathbf{S}$. mansoni, the Swiss albino mice used in this study showed the same level of concomitant immunity observed in the $\mathrm{C}_{3} \mathrm{H}$ mice employed by PERESAN \& CIOLI 4. The strain of parasite also does not interferen with the concomitant immunity produced. In this 'way', we used the LE strain of S. mansoni, whereas PERESAN \& CIOLI ${ }^{4}$ used a Puerto Rican strain of the trematode.

The fact that concomitant immunity can be observed in the absence of skin and pulmonary parasite migration, in the same degree of that obtained after natural infection, suggests that the most important stimulus for the establishment of resistance to a challenge infection occurs in the portal system, independent of the prior presence of younger stages of the parasite in the skin and lungs. This point of view is reinforced by SMITHERS \& GAMMAGE $^{7}$ and SMITHERS \& MILLER 8 who showed the evidence of two distinct mechanisms in the protective immunity, in murine schistosomiasis. One of these mechanisms takes place in the skin, where the infective cercariae die, and can be induced by prior exposition of mice to irradiate cercariae and by transcutaneous infection of normal cercariae in natural infection. The other mechanism occurs after parasite mi- 
ROCHA, M. O.; COELHO, P. M. Z. \& MELLO, R. T. - Schistosoma mansoni: importance of skin and pulmonary phases to concomitant immunity in albino mice. Rev. Inst. Med. trop. São Paulo 27:86-88, 1985.

gration to the portal system, and it is not induced by irradiate cercariae.

Finally, the present data reinforce the conclusions of PERESAN \& CIOLI ${ }^{4}$ and ourselves (ROCHA et al.5) that the skin and pulmonary migrations of schistosomula do not affect the degree of concomitant immunity.

\section{RESUMO}

Schistosoma mansoni: a importância das fases cutânea e pulmonar na imunidade concomitante, no camundongo albino

Esquistossômulos com 14 dias de idade, obtidos de camundongos previamente infectados, foram cirurgicamente transferidos para a veia porta de camundongos receptores. Outro grupo de camundongos foi infectado com cercárias por via transcutânea. Noventa dias após, aqueles grupos foram desafiados com 100 cercárias, transcutaneamente, assim como o grupo controle. Duas semanas mais tarde, os animais foram perfundidos e os vermes - maduros e imaturos - contados separadamente. Diferenças estatisticamente significativas foram observadas na recuperação dos vermes imaturos, quando o grupo controle foi comparado com aqueles grupos infectados duas vezes. $\mathrm{Ne}$ nhuma diferença estatística foi detectada entre o grupo infectado transcutaneamente e o grupo infectado por inoculação do verme na veia porta. Os resultados demonstraram que a su. pressão da migração do parasito através da pele e dos pulmões não interfere no desenvolvimento da chamada imunidade concomitante.

\section{ACKNOWLEDGEIMENT}

The Authors are grateful to Prof. Paul Williams for reviewing the English text.

\section{REFERENCES}

1. BARBOSA, M. A.; PELLEGRINO, J.; COELHO, P. M. z. \& SAMPAIO, I. E: M. - Quantitative aspects of the migration and evolutive asynchronism of Schistosoma mansoni in mice. Rev. Inst. Med. trop. São Paulo 20: 121-132, 1978.

2. DEAN, D. A.; BUKOWSKI, M. A. \& CHEEVER, A. W. - Relationship between acquired resistance, portal hy. pertension, and lung granulomas in ten strains of mice infected with Schistosoma mansoni. Am. J. Trop. Med. Hyg. 30: 805-814, 1981

3. PELLEGRINO, J. \& SIQUEIRA, A. F. - Técnica de perfusão para colheita de Schistosoma mansoni em cobaias experimentalmente infestadas. Rev. Bras. Malariol. Doenças Trop. 8: 589-597, 1956.

4. PERESAN, G. \& CIOLI, D. - Resistance to cercarial challenge upon transfer of Schistosoma mansoni into mice. Am. J. Trop. Med. Hyg. 29: 1258-1262, 1980.

5. ROCHA, M. O.; COELHO, P. M. Z. \& MELLO, R. T. - Schistosoma mansoni: o papel de migração pela pele e pulmōes na determinação da resposta imunoprotetora. VI Congr. Bras. Parasit., Belo Horizonte, Brasil, 1981.

6. ROCHA, M. O. \& COELHO, P. M. Z. - The importance of skin and pulmonary phases to the development of Schistosoma mansoni in albino mice. Rev. Inst. Med. trop. São Paulo 22: 157-163, 1980.

7. SMITHERS, S. R. \& GAMMAGE, K. - The recovery of Schistosoma mansoni from the skin, lungs and hepatic portal system of naive mice and mice previously exposed to S. mansoni: evidence for two phases of parasite attrition in immune mice. Parasitology 80: 289$300,1980$.

8. SMITHERS, S. R. \& MILLER, K. L. - Protective immunity in murine schistosomiasis mansoni: evidence for two distinct mechanisms. Am. J. Trop. Med. Hyg. 29: 832-841, 1980 .

Recebido para publicação em 13/3/1984. 